Matematikai Közlemények

V. kötet, 2017

doi:10.20312/dim.2017.03

\title{
A WRF oszlopmodell különböző felszínközeli réteg parametrizációinak validálása a PABLS mérésekkel
}

\author{
Virág Szabolcsné Németh Rita \\ ELTE TTK, Meteorológiai Tanszék \\ szabolcsnevirag@gmail.com \\ Breuer Hajnalka \\ ELTE TTK, Meteorológiai Tanszék \\ bhajni@nimbus.elte.com
}

\begin{abstract}
ÖSSZEFOGLALÓ. Fő feladatunk a légkör felszínközeli rétegében zajló mikrometeorológiai folyamatok modellezésének lehetséges fejlesztési irányainak feltérképezése. Ebben a munkában a WRF oszlopmodell planetáris határréteg és felszínközeli réteg sémák különböző kombinációit teszteltük. Az eredmények azt mutatják, hogy a planetáris határréteg parametriziójának megfelelő megválasztása kulcsfontosságú, szemben a felszínközeli séma megválasztásával.

ABSTRACT. Our main task is to map the possible development areas of the modelling of microscale processes in the atmospheric surface layer. In this study the single column version of the WRF model was used to test the different available combinations of planetary boundary layer (PBL) and surface parametrizations. Results show that the proper choice of PBL scheme is the key, as opposed to the choice of surface layer scheme.
\end{abstract}

\section{Bevezetés}

A felszínközeli réteg a planetáris határréteg legalsó része, ahol a turbulens fluxusok a magnitúdójuk kevesebb, mint 10 \%-ával változnak [1]. Itt zajlik a legjelentősebb momentum-, hő- és nedvességcsere. Állapota meghatározza a szárazföld-légkör kölcsönhatásokat [2]. Ez a legkevésbé ismert része a határrétegnek, modellezésének és mérésének nehézségét az itt zajló mikroskálájú folyamatok, például a turbulencia okozzák. A turbulens áramlást összetett és gyakran kaotikus viselkedés jellemzi, becslése mégis elengedhetetlen a prognosztikus modellek megfelelö müködéséhez. Tekintve, hogy a turbulens folyamatok explicit leírásához mikrométer léptékre lenne szükség, a mozgás nincs leírva a modellben, csupán azok hatását becsüljük (pl. transzportált hö). Ezek a becslések továbbra is fizikai egyenletek segítségével történnek az ún. parametrizációkban. A kutatás a Weather Reasearch and Forecasting (WRF) 3.8 oszlopmodelljének segítségével készült. Elsősorban a modell planetáris határréteg (PBL) és felszínközeli réteg (SFC) séma parametrizációit teszteltük. A felszínközeli réteg sémák kezelik a hőfluxusokat, a nedvességet és a momentumokat a légkör alsó részében. Olyan együtthatókat állapítanak meg, amik lehetővé teszik nedvesség fluxusok számítását. Ezek a fluxusok biztosítják az alsó határfeltételeket a PBL sémákban zajló vertikális transzporthoz [3]. A különféle parametrizációk hatékonyságának vizsgálatához mérésekre van szükség. Elengedhetetlen a vertikálisan minél több mintavétel a modell validálásához. 


\section{Adatok}

A validáláshoz felhasznált adatok a PABLS'15 kutatási project keretében készültek a szegedi reptér mellett kvadrokopteres szondás felszállásokkal [4]. Összesen 21 felszállás adatsorát használtuk fel, melyek 2015. július 16-áról 17-ére virradó éjszaka zajlottak. A mérések a felszíntől, 84 méter magasról, körülbelül 150 méter tengerszint feletti magasságig készültek és közel 50 centiméterenként regisztrálták a légköri állapothatározókat. Felhasználtuk a hőmérséklet, nyomás, relatív nedvesség, szélsebesség és szélirány adatsorokat.

\section{Használt parametrizációk}

Lefuttattuk az oszlopmodellt a megfelelő időszakra az összes WRF-ben beállítható planetáris határréteg és felszínközeli réteg séma kombinációval. Ebből összesen 26 volt. A kombinációk és az összes felhasznált planetáris határréteg (PBL) parametrizáció és felszínközeli réteg (SFC) séma parametrizáció az 1. táblázatban és a 2. táblázatban kerül bemutatásra. A turbulens áramlás lezárási problémájának megoldására különböző rendü lezárásokat használnak az egyes planetáris határréteg parametrizációk [1]. Az általunk tesztelt parametrizációk elsőrendü, másodrendű vagy másfeles rendủ lezárással rendelkeznek. Két fő osztálya a turbulens lezárásnak a lokális és a nemlokális lezárás. Lokális lezáráskor egy ismeretlen mennyiség bárhol a térben az ugyanabban a pontban lévő ismert mennyiségek értékeivel vagy gradienseivel van parametrizálva. Nemlokális lezáráskor ellenben az egy pontbeli ismeretlen mennyiséget a tér sok pontjából vett ismert értékekkel parametrizálják [1]. A planetáris határréteg magasságának operatív definíciója is két alapvető osztályba sorolható a különféle sémáknál. Az első osztály a bulk Richardson szám segítségével számít planetáris határréteg magasságot egy előre meghatározott kezdeti szintről. A második osztálya, amikor azon a szinten állapítja meg a planetáris határréteg tetejét, ahol a turbulens kinetikus energia profil egy elöre meghatározott küszöbértékig lecsökken [5]. Az 1. táblázatban minden PBL beállításhoz olvasható a turbulens lezárás rendje, illetve, hogy lokális vagy nemlokális osztályba sorolható a lezárás. Ezen kívül megtalálható, hogy K-profil alapján vagy turbulens kinetikus energia (TKE) alapján számol. A planetáris határréteg magaságának (PBLH) meghatározása az egyes sémákban a bulk Richardson szám ( $\left.\mathrm{Ri}_{\mathrm{b}}\right)$ vagy a TKE segítségével történik. A WRF modell SFC sémái és felhasznált 26 különböző PBL/SFC kombináció felsorolása a 2. táblázatban látható.

\begin{tabular}{|c|c|c|c|c||}
\hline $\begin{array}{c}\text { PBL } \\
\text { beállítás }\end{array}$ & PBL séma & $\begin{array}{c}\text { Lezárás rendje és } \\
\text { osztálya }\end{array}$ & $\begin{array}{c}\text { Számolás } \\
\text { alapja }\end{array}$ & $\begin{array}{c}\text { PBLH } \\
\text { definíció }\end{array}$ \\
\hline \hline 1 & Yonsei University séma & 1,0 nemlokális & $\mathrm{K}$-profil & $\mathrm{Ri}_{\mathrm{b}}$ \\
\hline 2 & Mellor-Yamada-Janjic séma & 1,5 lokális & $\mathrm{TKE}$ & $\mathrm{TKE}$ \\
\hline 3 & NCEP Global Forecast System séma & 1,0 nemlokális & $\mathrm{K}$-profil & $\mathrm{Ri}_{\mathrm{b}}$ \\
\hline 4 & Eddy-diffúziós tömegfluxus QNSE séma & 1,5 lokális & $\mathrm{TKE}$ & $\mathrm{TKE}$ \\
\hline 5 & 2,5 szintü Mellor-Yamada-Nakanishi-Niino séma & 1,5 lokális & $\mathrm{TKE}$ & $\mathrm{TKE}$ \\
\hline $\mathbf{6}$ & 3 szintü Mellor-Yamada-Nakanishi-Niino séma & 2,0 lokális & $\mathrm{TKE}$ & $\mathrm{TKE}$ \\
\hline 7 & Asszimetrikus Konvektív Modell 2 séma & 1,0 lokális/nemlokális & $\mathrm{K}$-profil & $\mathrm{Ri}$ \\
\hline 8 & Bougeault-Lacarrere séma & 1,5 lokális & $\mathrm{TKE}$ & $\mathrm{TKE}$ \\
\hline 9 & University of Washington séma & 1,5 lokális & $\mathrm{TKE}$ & $\mathrm{Ri}_{\mathrm{b}}$ \\
\hline 11 & Shin-Hong ,scale-aware” séma & 1,0 nemlokális & $\mathrm{K}-\mathrm{profil}$ & $\mathrm{Ri}_{\mathrm{b}}$ \\
\hline 12 & Grenier-Bretherton-McCaa séma & 1,5 lokális & $\mathrm{TKE}$ & $\mathrm{Ri}_{\mathrm{b}}$ \\
\hline
\end{tabular}




\begin{tabular}{||c|c||}
\hline $\begin{array}{c}\text { SFC } \\
\text { beállítás }\end{array}$ & SFC séma \\
\hline \hline 1 & Módosított MM5 Monin-Obukhov séma \\
\hline 2 & Monin-Obukhov (Janjic) séma \\
\hline 3 & NCEP Global Forecast System séma \\
\hline 4 & QNSE felszínközeli réteg séma \\
\hline 5 & Mellor-Yamada-Nakanishi-Niino séma \\
\hline 7 & Pleim-Xiu séma \\
\hline 91 & Régi MM5 séma \\
\hline
\end{tabular}

\begin{tabular}{||cc|cc|cc|cc||}
\hline \multicolumn{7}{|c||}{ PBL/SFC } \\
\hline \hline 1. & $1 / 1$ & 8. & $5 / 5$ & 15. & $7 / 7$ & 22. & $9 / 91$ \\
\hline 2. & $1 / 91$ & 9. & $5 / 91$ & 16. & $7 / 91$ & 23. & $11 / 1$ \\
\hline 3. & $2 / 2$ & 10. & $6 / 1$ & 17. & $8 / 1$ & 24. & $11 / 91$ \\
\hline 4. & $3 / 3$ & 11. & $6 / 2$ & 18. & $8 / 2$ & 25. & $12 / 1$ \\
\hline 5. & $4 / 4$ & 12. & $6 / 5$ & 19. & $8 / 91$ & 26. & $12 / 91$ \\
\hline 6. & $5 / 1$ & 13. & $6 / 91$ & 20. & $9 / 1$ & & \\
\cline { 1 - 4 } 7. & $5 / 2$ & 14. & $7 / 1$ & 21. & $9 / 2$ & & \\
\hline
\end{tabular}

2. táblázat: A használt felszínközeli réteg sémák és a planetáris határréteg (PBL) és felszínközeli réteg (SFC) séma beállítások kombinációi

\section{Esettanulmány}

Az oszlopmodell futásához szükséges kezdeti értékeket mind az aznap déli szegedi rádiószondás felszállásból, mind a Global Forecast System (GFS) 12 UTC-re vonatkozó adataiból előállítottuk. Az egységes mértékegységre számított és lineáris interpolálással közös magassági szintekre hozott modelleredmények és mérési adatsorok statisztikai vizsgálatát $\mathrm{R}$ programmal és programcsomagokkal végeztük. A felhasznált állapothatározók a hőmérséklet, a nyomás, a relatív nedvesség, a szélsebesség és a szélirány. A hőmérséklet és a nyomás segítségével potenciális hőmérsékletet is előállítottuk, mely a légköri stabilitás indikátora.

Az 1. ábra a 19:10 időponthoz tartozó 12 UTC-kor indított modellfutás potenciális hőmérséklet és relatív nedvesség értékeit mutatja. Egyszerre látható mind a 26 féle beállítással számított érték erre az időpontra, piros színnel a GFS adatokból, zöld színnel a szonda által mért adatokból származó kezdeti értékkel készült modelleredmények. Vastag kék színnel a 19:10-kor készült mérést jelöltük.
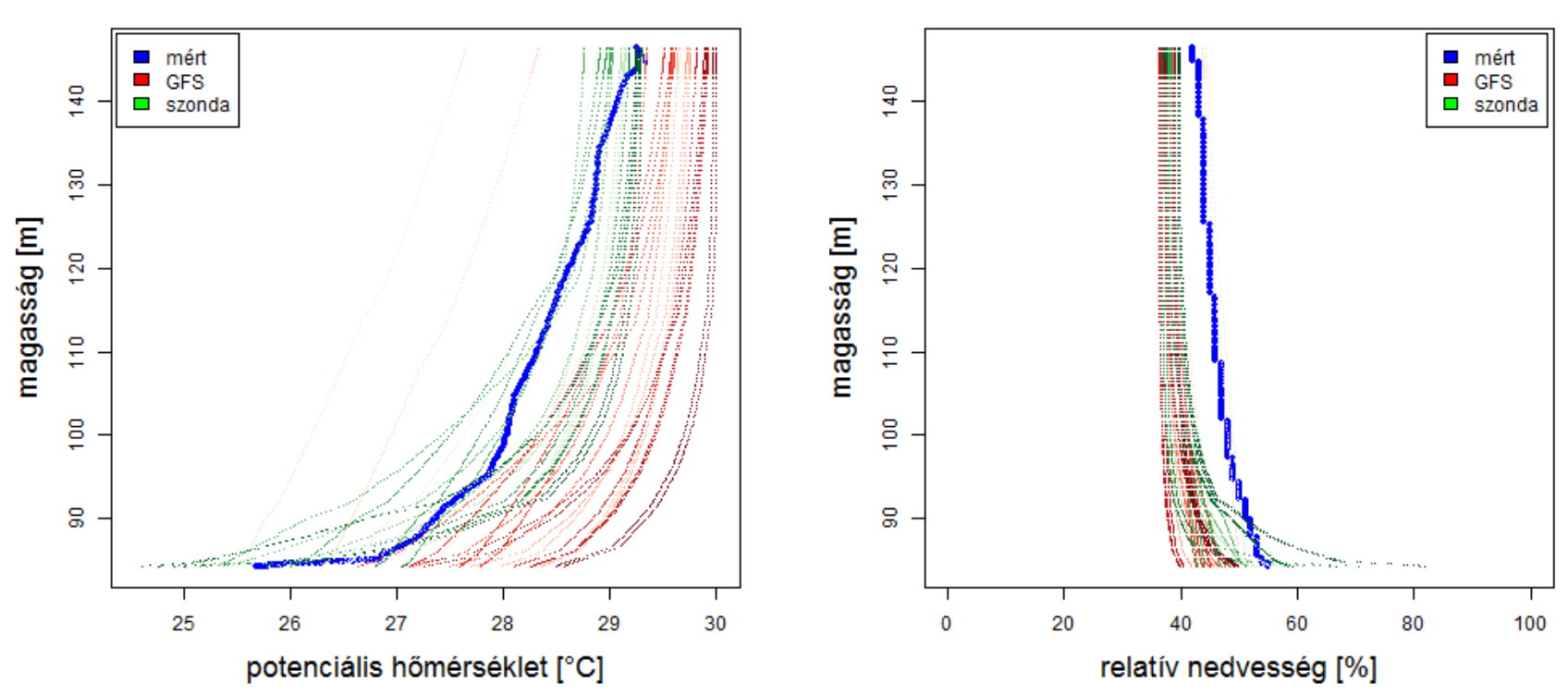

1. ábra. A 19:10 időponthoz tartozó mért és modellezett potenciális hőmérséklet és relatív nedvesség változása a magassággal a felszínközeli légrétegben 
Figyelembe véve, hogy a kapott potenciális hőmérséklet jelentősen függ a helyes inicializációtól, ezért a vertikális gradiensét is meghatároztuk, mely inkább utal a parametrizációk fizikai működésére. A potenciális hőmérséklet gradiense látható a 2. ábrán a 19:10 időpontra vonatkozóan. Ezen megfigyelhető, hogy bár a modellezett potenciális hőmérséklet egyes beállításokra akár 2 Celsius fokos tévedést mutat, a görbék menete hasonlít a mérési görbe menetéhez. A 2. ábra boxplot diagramján láthatóak a GFS kezdeti értékkel számított gradiensek hibaértékei. A mért adatoktól vett eltérés nullához közeli mind a 26 különböző PLB/SFC beállításra. Bár a GFS kezdeti értékü potenciális hőmérséklet értékek néhány ${ }^{\circ} \mathrm{C}$-kal magasabb értéket mutattak a mérésnél, gradiensükben mégis kellően kicsi a különbség. A legkevésbé pontos beállításnak az 5-ös beállítás bizonyult. A többi beállítás a modellezett meteorológiai változótól függően viselkedett. Például relatív nedvességre a 4-es beállítás adta a legkisebb hibát, szélirányban a 20, 21, 22, 25, 26-os beállítások hasonlóan kiemelkedően viselkedtek. Ellenben a szélsebességre a 25-ös és 26-os beállítások a legpontatlanabbak.
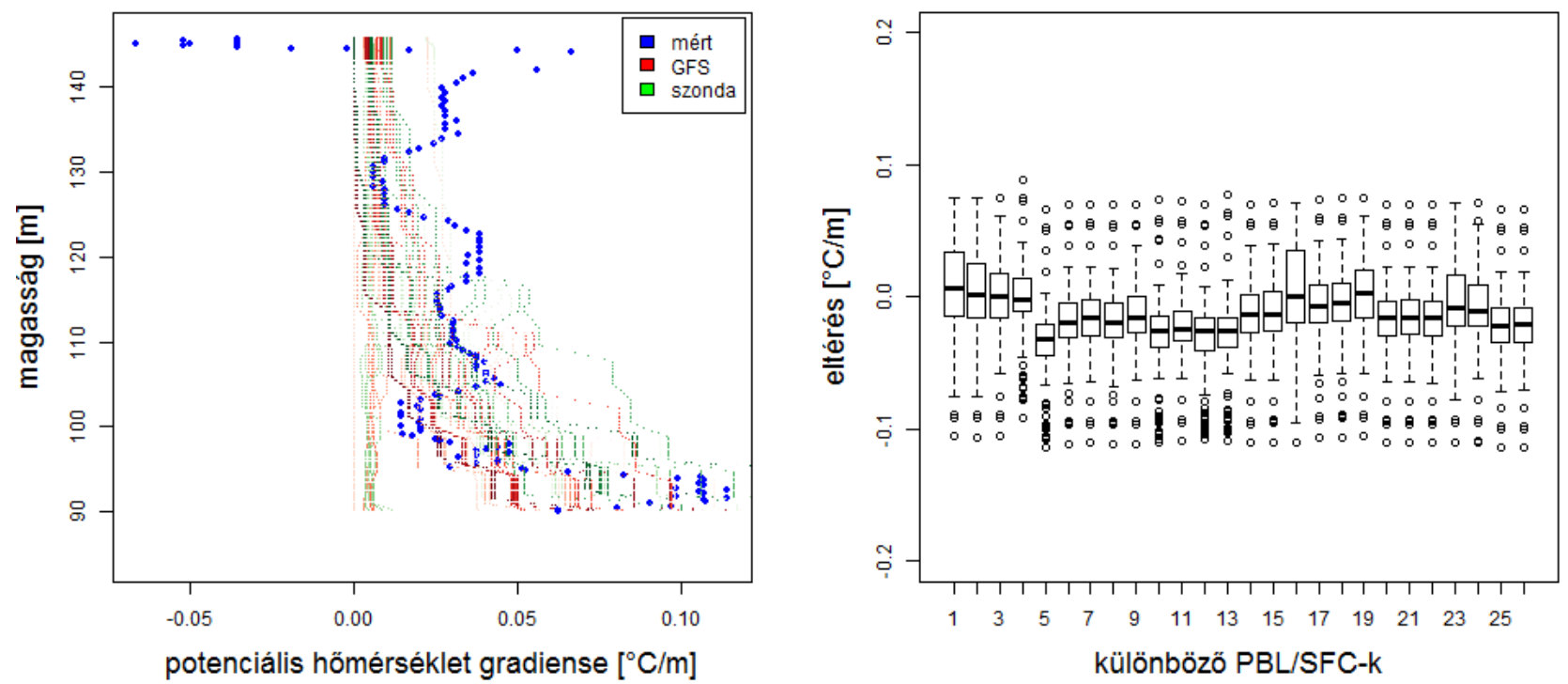

2. ábra. A 19:10 időponthoz tartozó mért és modellezett potenciális hőmérséklet gradiensének változása a magassággal és a potenciális hőmérséklet gradiensének GFS kezdeti értékekkel indított eredményei boxplot diagrammja

Az egyes parametrizációk egymással való kapcsolatát klaszteranalízissel vizsgáltuk meg. A klaszterek meghatározásának alapja az egyes különbség-adatsorok fökomponens analízise volt. Az első két fökomponens alapján lettek meghatározva az egyes csoportok. Ehhez a K-alapú csoportanalízishez a CLARA módszert használtuk [6]. A 26 féle beállításból 5 klasztert állítottunk elő, kisebb klaszterszám esetén az egyes klaszterelemek közötti távolság jelentősen megnövekedett. Az analízist az egyes modellbeállítások mérésektől vett hibaértékeire készítettük el. Az 5-ös beállítás majdnem minden esetben kiugró volt, nagyságrendileg hibás értékeket adott. Így az analízisből kiszürtük. A többi beállításnál az figyelhető meg, hogy az ugyanazt a PBL sémát, de különböző SFC sémát használók eredményei nagyon hasonlítanak egymáshoz. Ebböl azt a következtetést vonhatjuk le, hogy a prognosztikus modellben a megfelelő PBL-parametrizáció választása a kulcsfontosságú, az SFC-séma kisebb különbségeket okoz. A 19:10 időponthoz tartozó hőmérsékletek hibaértékeire elvégzett klaszteranalízis GFS kezdeti értékekkel indítva a 3.ábrán, szonda kezdeti értékekkel a 4. ábrán látható. Bár az 1. ábrán megfigyelhető a pontos kezdeti érték fontossága, itt azt láthatjuk, hogy a fökomponens analízis különböző kezdeti értékekkel is hasonló helyre sorolja az egyes PBL/SFC sémákat. 


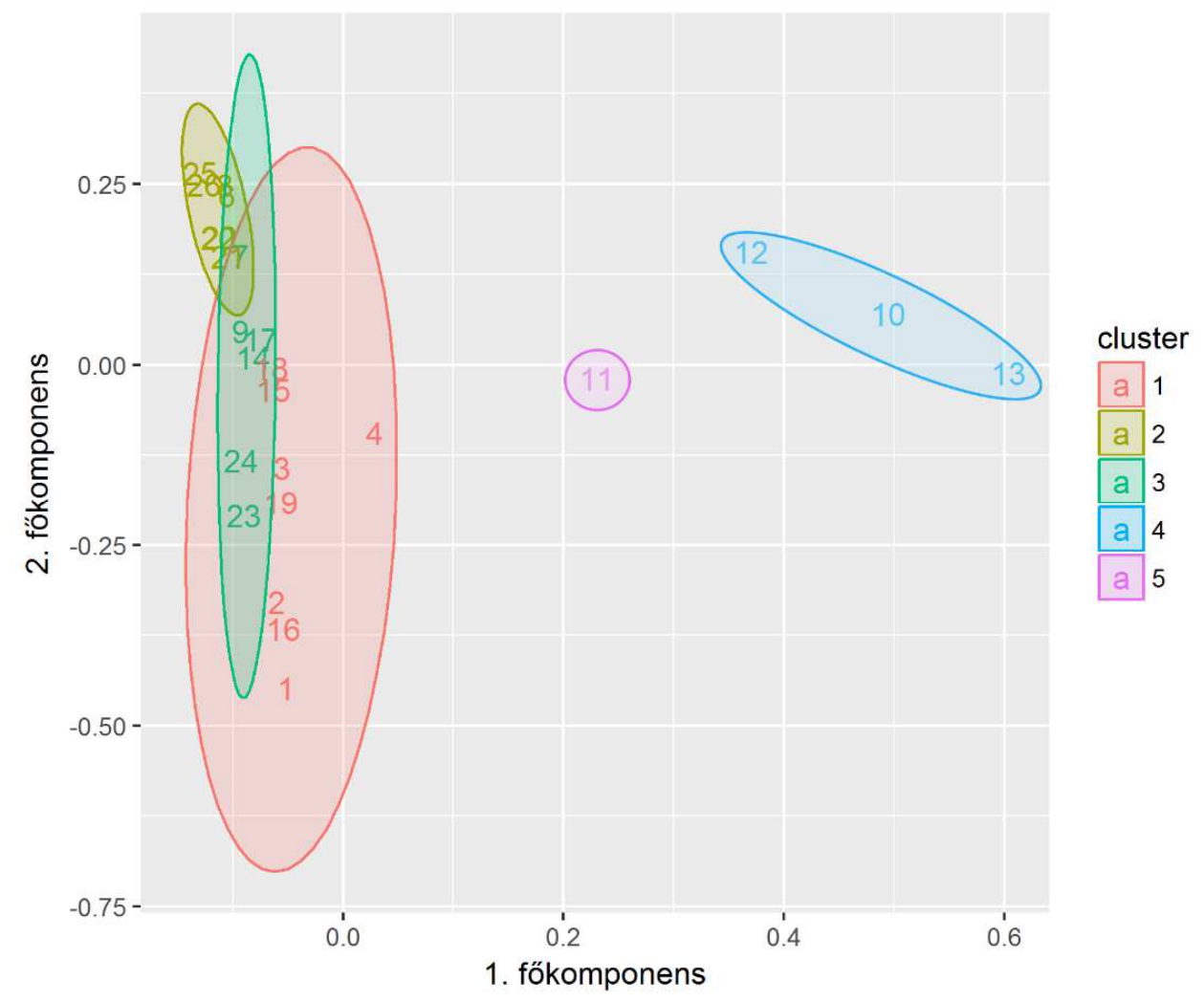

3. ábra. A 19:10 időponthoz tartozó GFS kezdeti értékekkel indított hőmérsékletértékek 26 különböző PBL/SFC beállítás klaszteranalízis ábrája

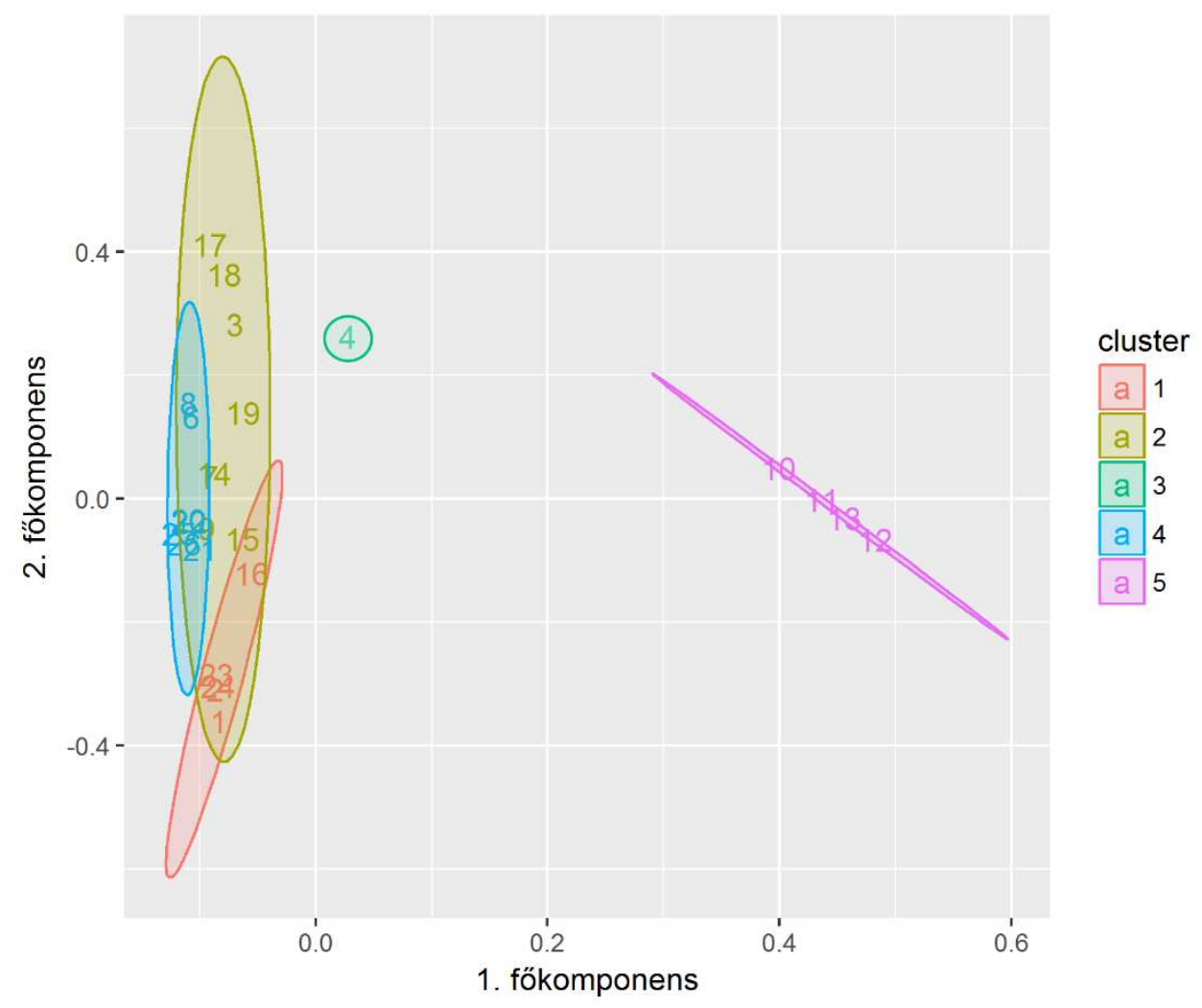

4. ábra. A 19:10 időponthoz tartozó szonda kezdeti értékekkel indított hőmérsékletértékek 26 különböző PBL/SFC beállítás klaszteranalízis ábrája 
Ha a PBL sémák szerint 12 klasztert állítunk elö, akkor az egyes PBL szerinti csoportosulás a legtöbb esetben megfigyelhetö. Kivételt képez ez alól a 6-os PBL parametrizáció SFC kombinációi, melyek az esetek jelentős részében 2 különböző klasztert képeznek, így ezeket a későbbiekben további vizsgálatoknak vetjük alá. Az eltérés legvalószínübb oka, hogy a 6-os PBL séma rendelkezik a turbulencia legpontosabb közelítésével (másodrendű lezárású), amely esetén már a különböző SFC-k hatása nem lesz elhanyagolható. Ha az SFC-k számának megfelelö klaszterszámot használunk, a csoportok továbbra is a különböző PBL sémák szerint csoportosulnak, és nem az SFC-k szerint.

\section{5. Összefoglaló}

Legfontosabb eredményünk, hogy a felszínközeli réteg séma megválasztása kevéssé fontos, mint a megfelelö planetáris határréteg parametrizáció. Ennek legoptimálisabb megválasztása a modellezni kívánt meteorológiai állapothatározó függvénye. Továbbá az Eddy-diffúziós tömegfluxussal számított planetáris határréteg parametrizáció (4-es PBL beállítás, 5. sorszám) bizonyult a legkevésbé jónak.

\section{Irodalomjegyzék}

[1] Stull, R. B., An Introduction to Boundary Layer Meteorology, Kluwer Academic Publishers, Dordrecht, 1988, doi:10.1007/978-94-009-3027-8.

[2] Jiménez, P. A., Dudhia, J., González-Rouco, J. F., Navarro, J., Montávez, J. P., GarcíaBustamante, E., A revised scheme for the WRF surface layer formulation, Monthly Weather Review, 140 (2012), 898-918, doi:10.1175/MWR-D-11-00056.1.

[3] Bianco, L., Surface layer parameterization in WRF. ATOC 7500: Mesoscale Meteorological Modeling, Presentation, 2008.

[4] Tordai, Á. V., Mikrometeorológiai mérőrendszer kialakítása és alkalmazása síkvidéki, magashegyi és barlangi körülmények között, TDK dolgozat, Eötvös Loránd Tudományegyetem, Budapest, 2016.

[5] Banks, R. F., Tiana-Alsina, J., Baldasano, J. M., Rocadenbosch, F., Papayannis, A., Solomos, S., Tzanis, C. G., Sensitivity of boundary-layer variables to PBL schemes in the WRF model based on surface meteorological observations, lidar, and radiosondes during the HygrA-CD campaign, Atmospheric Research, 176-177 (2016), 185-201, doi:10.1016/j.atmosres.2016.02.024.

[6] Kaufman, L., Rousseeuw, P. J., Finding Groups in Data: An Introduction to Cluster Analysis, Wiley, New York, 1990, doi:10.2307/2532178. 